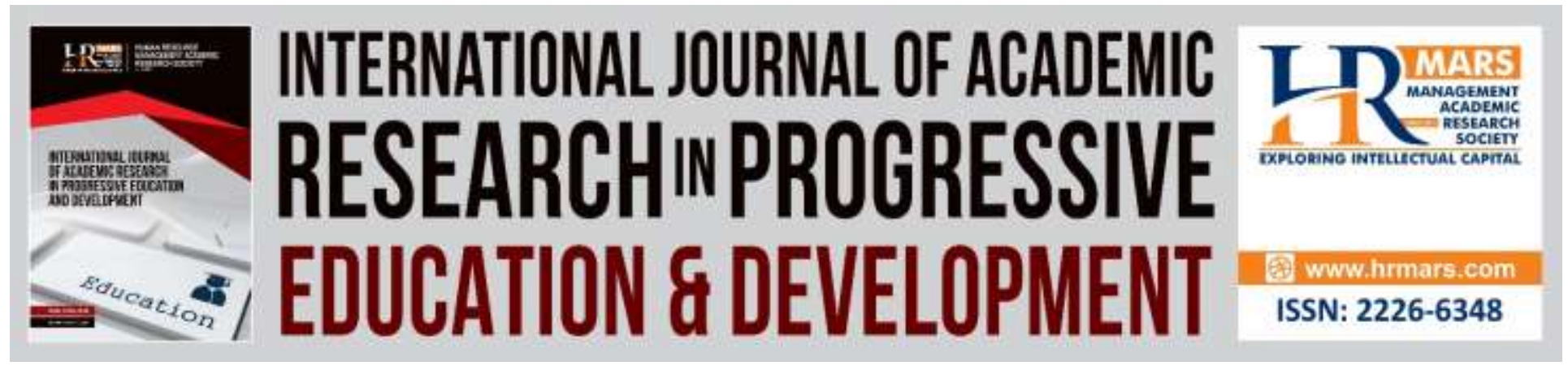

\title{
Design and Development of Dyscalculia Checklist Instrument
}

\author{
Yoong Soo May, Noor Aini Ahmad
}

To Link this Article: http://dx.doi.org/10.6007/IJARPED/v9-i2/7291

DOI:10.6007/IJARPED/v9-i2/7291

Received: 25 March 2020, Revised: 26 April 2020, Accepted: 15 May 2020

Published Online: 18 June 2020

In-Text Citation: (May \& Ahmad, 2020)

To Cite this Article: May, Y. S., \& Ahmad, N. A. (2020). Design and Development of Dyscalculia Checklist Instrument. International Journal of Academic Research in Progressive Education and Development, 9(2), 170-178.

Copyright: (C) 2020 The Author(s)

Published by Human Resource Management Academic Research Society (www.hrmars.com)

This article is published under the Creative Commons Attribution (CC BY 4.0) license. Anyone may reproduce, distribute, translate and create derivative works of this article (for both commercial and non-commercial purposes), subject to full attribution to the original publication and authors. The full terms of this license may be seen at: http://creativecommons.org/licences/by/4.0/legalcode

\section{Vol. 9(2) 2020, Pg. 170 - 178}

Full Terms \& Conditions of access and use can be found at http://hrmars.com/index.php/pages/detail/publication-ethics 


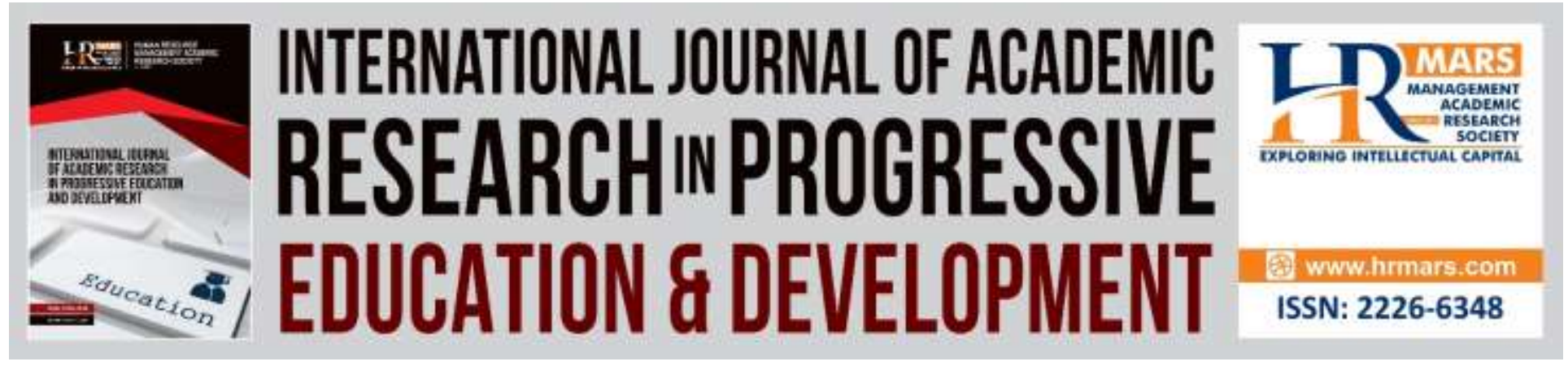

\title{
Design and Development of Dyscalculia Checklist Instrument
}

\author{
Yoong Soo May ${ }^{1}$, Noor Aini Ahmad ${ }^{2}$ \\ Department of Special Education, Faculty of Human Development, Universiti Pendidikan Sultan \\ Idris, Malaysia.
}

\begin{abstract}
The purpose of this study is to design and develop Dyscalculia Checklist Instrument (DCI) for dyscalculic pupils in primary schools. Dyscalculia is a learning disability in mathematics. Unlike dyslexia, there is still no checklist available in our country to detect these dyscalculic pupils. If they are not being detected, these pupils will continue being left out and labelled, with no proper intervention or diagnosis given to them. This study will employ Design and Development Research (DDR) approach. During phase one, needs analysis will be carried out to 90 teachers and 90 parents. This is to identify whether there is a need to develop a checklist for dyscalculic pupils in primary schools. During phase two, Fuzzy Delphi Method (FDM) will be carried out by inviting 11 experts in the fields of dyscalculia, special education, and instrumentation. During phase three, Nominal Group Technique (NGT) will be implemented. The experts will vote and rank for the constructs and items in $\mathrm{DCl}$. Purposive sampling method will be employed in this study. The data will be analysed using descriptive and inferential statistics. $T$-test will be used to compare the data of needs to develop DCl between teachers and parents. ANOVA will be used to compare the data of needs to develop DCl between Malay-Medium National School (SK), National-Type Chinese Primary School (SJKC), and National-Type Tamil Primary School (SJKT). Then, the researcher will obtain the threshold, $d$ value and experts' consensus value to design, develop and evaluate the constructs and items in $\mathrm{DCl}$.

Keywords: Dyscalculia, Checklist, Design and Development Research (DDR), Fuzzy Delphi Method (FDM), Nominal Group Technique (NGT).

\section{Introduction}

There are six categories of special needs pupils, which include pupils with; (1) visual impairment; (2) hearing impairment; (3) speech difficulties; (4) physical disabilities; (5) multiple disabilities; and (6) learning disabilities such as autism, Down's Syndrome, attention deficit hyperactivity disorder, and dyslexia (Ministry of Education Malaysia, 2013). However the term dyscalculia did not appear in Malaysia Education Blueprint 2013-2025.
\end{abstract}


There are four to six percent of the pupils among the population are dyscalculic (Bird, 2017). The presence of dyscalculic may affect mathematics performance among normal students (Chin, Pang, Wong, Tan, \& Lee, 2014). Students with special needs should be given full attention by teachers (Ahmad, 2018). Many students find mathematics as a difficult subject (May \& Ahmad, 2018), especially dyscalculic pupils. In accordance, teachers need to provide teaching that is in line with the needs of the pupils (Yunus \& Ahmad, 2019). If these pupils are not being detected, they will continue to be left out or labelled. Thus, a dyscalculia checklist has to be developed in order to detect the dyscalculic pupils in our normal classrooms.

The purpose of this study is to design and develop Dyscalculia Checklist Instrument (DCI) for dyscalculic pupils in primary schools. Three objectives to achieve the main purpose are; (1) to identify the need to develop Dyscalculia Checklist Instrument (DCI) for dyscalculic pupils in primary schools; (2) to design and develop Dyscalculia Checklist Instrument (DCI) based on opinions and consensus from experts; and (3) to evaluate the suitability of Dyscalculia Checklist Instrument (DCl) based on opinions and consensus from experts.

\section{Methodology}

Every study needs methodology as a way to obtain the findings. The method or methodology section consists of skeleton of the study (Perry \& Nichols, 2015). The nature of this study is Design and Development Research (DDR) model. Three phases in DDR are; (1) phase one: needs analysis; (2) phase two: design and development; and (3) phase three: evaluation.

\section{Research Design}

There are two categories of Design and Development Research (DDR). Table 1 shows two categories of developmental research. Type one is named as Product and Tool Research, whereas Type Two is named as Model Research. Type One research is a study on the specific product or tool design and development projects; whereas Type Two research is a study of model development, validation or use. The outcomes of Type One research are lessons learned from developing specific products and analyzing the conditions which facilitate their use. On the other hand, the outcomes of Type Two research are new design and development procedures or models, and conditions which facilitate their use. The category of the developmental research that applied in this study is Type Two research. 
INTERNATIONAL JOURNAL OF ACADEMIC RESEARCH IN PROGRESSIVE EDUCATION AND

DEVELOPMENT

Vol. 9, No. 2, 2020, E-ISSN: 2226-6348 @ 2020 HRMARS

Table 1

Two Categories of Developmental Research. Adapted from Richey \& Klein, 2007

\begin{tabular}{|c|c|c|}
\hline & $\begin{array}{c}\text { Type One } \\
\text { (Product and Tool Research) }\end{array}$ & $\begin{array}{c}\text { Type Two } \\
\text { (Model Research) }\end{array}$ \\
\hline Emphasis & $\begin{array}{l}\text { Study on the specific product or tool } \\
\text { design and development projects. }\end{array}$ & $\begin{array}{l}\text { Study of model development, } \\
\text { validation or use. }\end{array}$ \\
\hline Outcomes & $\begin{array}{l}\text { Lessons learned from developing } \\
\text { specific products and analyzing the } \\
\text { conditions which facilitate their use. }\end{array}$ & $\begin{array}{l}\text { New design and development } \\
\text { procedures or models, and conditions } \\
\text { which facilitate their use. }\end{array}$ \\
\hline
\end{tabular}

DDR is a research approach in which can provide reliable and usable information to practitioners in the fields of instructional technology and curriculum development (Alias, Siraj, Rahman, \& DeWitt, 2013). It was first proposed by Brown and Collins in 1990s. Currently, it is among the well-known methods in educational research. It is also known as developmental research, design research, design-based research, formative research, and design-cased (Sahrir, Alias, Ismail, \& Osman, 2012).

In short, DDR is yet a new research design which is applicable for the researchers to design and develop a product. These products can be a model, module, framework, questionnaire, guideline, and so on. DDR enrolled experts in the process of designing, developing, and evaluating a product. In this study, the researcher will design and develop a checklist for dyscalculia, which will be able to detect the dyscalculic pupils in primary schools.

\section{Phase One: Needs Analysis}

Three phases in discrepancy model are goal setting, performance measurement, and discrepancy identification (McKillip, 1987). Firstly, the researcher will identify the goal. The goal in this phase is to determine the needs to design and develop DCl for dyscalculic pupils in primary schools. Next, the researcher will collect and analyse the information based on the literature regarding the performance, characteristics, and existing data relevant to dyscalculic pupils in primary schools. After that, the researcher will identify the discrepancy which occurred when there are so many dyscalculic pupils among the population but yet there have no checklist being develop in order to detect these pupils.

The needs analysis survey will involve 90 teachers and 90 parents. The researcher will apply purposive sampling method in selecting the respondents. The inclusion criteria of teachers are; (1) they must have more than five years teaching experience; (2) they are teaching mathematics; and (3) they are teaching in SK, SJKC, or SJKT. On the other hand, the inclusion criteria of parents are; (1) they have at least a dyscalculic child; (2) their child is studying in SK, SJKC, or SJKT; and (3) they can understand simple English, Malay, or Chinese language. All of them must be voluntary to be involved in this study. Table 2 shows the sample involves in needs analysis survey. There are 30 teachers and 30 parents from SK, SJKC, and SJKT respectively. Thus, there will be a total of 180 respondents involved in this needs analysis survey. 
INTERNATIONAL JOURNAL OF ACADEMIC RESEARCH IN PROGRESSIVE EDUCATION AND

DEVELOPMENT

Vol. 9, No. 2, 2020, E-ISSN: 2226-6348 @ 2020 HRMARS

Table 2

Sample Involves in Needs Analysis Survey

\begin{tabular}{ccc}
\hline Schools Types & Number of Teachers & Number of Parents \\
\hline SK & 30 & 30 \\
SJKC & 30 & 30 \\
SJKT & 30 & 30 \\
Total & 90 & 90 \\
\hline
\end{tabular}

Notes, SK = Malay-Medium National School, SJKC = National-Type Chinese Primary School, SJKT = National-Type Tamil Primary School.

\section{Phase Two: Design and Development}

During this phase, the researcher will build the constructs and items in the checklist based on literature reviews. Fuzzy Delphi Method (FDM) will be carried out in this phase. Once the prototype of $\mathrm{DCl}$ has been developed, it will be sent to the eleven experts, attached with the consent form and the checklist for main construct and items of $\mathrm{DCl}$. This checklist is designed with seven-point likert scale to allow the experts to give ideas, critics, and make improvement. Based on the findings from the experts, the researcher will design and develop $\mathrm{DCl}$ which is suitable to detect dyscalculic pupils in primary schools.

The researcher will select eleven experts in the fields of dyscalculia, mathematics, and instrumentation to contribute in FDM. The criteria to select these experts are; (1) have more than five years experience in the expert field; (2) had done publication or research is his area; or (3) have more than five years experience in teaching mathematics, remedial education, or special education. The experts who are invited to join in this study do not know each other. This characteristic of anonymity is to ensure that all of the experts are able to express their opinions without bias or affected by any other experts.

\section{Phase Three: Evaluation}

This phase is the evaluation of DCl by experts. Nominal Group Technique (NGT) will be employed in this phase. NGT is a method that makes possible for a team or group to quickly come to a consensus on the relative importance of issues, problems, or solutions by aggregating individual importance ranking into a team's final priorities (Odu, 2017). Eleven experts will be invited to sit in a round table to evaluate the constructs and items in $\mathrm{DCl}$.

The researcher will employ the same purposive sampling and experts criteria in phase three evaluation. A number of eleven experts will be invited to participate in evaluation of $\mathrm{DCl}$. This is in accordance to Odu (2017) who stated that NGT should be formed comprising 9 to 12 persons who are expected to be knowledgeable about the issue for which the session in convened. The criteria of the experts during this phase are; (1) have more than five years experience in the expert field; (2) had done publication or research is his area; or (3) have more than five years experience in teaching mathematics, remedial education, or special education. 
Vol. 9, No. 2, 2020, E-ISSN: 2226-6348@ 2020 HRMARS

\section{Instruments}

An instrument is a tool or procedure to collect data systematically (Lay \& Khoo, 2016). Table 3 shows the instruments to be used in three phases of the study. Five instruments to be used in this study are; (1) needs analysis questionnaire for teachers; (2) needs analysis questionnaire for parents; (3) content validity questionnaire for needs analysis; (4) Checklist for FDM; and (5) Checklist for NGT.

Table 3

Instruments in Three Phases of the Study

\begin{tabular}{ll}
\hline \multicolumn{1}{c}{ Phase } & \multicolumn{1}{c}{ Instruments } \\
\hline 1. Needs Analysis & Needs Analysis Questionnaire for Teachers \\
& Needs Analysis Questionnaire for Parents \\
& Content Validity Questionnaire for Needs Analysis \\
2. Design and Develop & Checklist for Fuzzy Delphi Method (FDM) \\
3. Evaluation & Checklist for Nominal Group Technique (NGT) \\
\hline
\end{tabular}

\section{Research Procedures}

Before the research is being carried out, the researcher will apply for the ethical approval from Sultan Idris Education University (UPSI). After that, the letters of transmittal requesting official permission from Ministry of Education Malaysia, State Education Departments, and District Education Offices will be obtained.

Then, the researcher will distribute 180 needs analysis questionnaires to 90 teachers and 90 parents in SK, SJKC, and SJKT. After the data is being analysed, FDM will be administered. Eleven experts will be selected based on the certain criteria. The researcher will deliver the checklist of FDM and consent form of experts by sending email (Jamil, Siraj, Hussin, Noh, \& Sapar, 2019).

Next, NGT will be carried out during the evaluation phase. The researcher will carry out NGT session in six stages; (1) eleven experts are being gathered; (2) the researcher will present the constructs and items of DCl to the experts; (3) the experts write down ideas individually; (4) each expert will present one idea to the others; (5) all of the experts will clarify and evaluates all constructs and items; and (6) the results are voted and rated with rankings.

\section{Data Analysis Procedures}

During the first phase, the data in the needs analysis survey will be analysed by using Statistical Package for Social Science (SPSS) version 23 to obtain the descriptive and inferential statistics. The descriptive statistics in this study includes percentages and means, whereas inferential statistics in this study are $t$-test and analysis of variance (ANOVA). Table 4 shows the scale of agreement for needs analysis questionnaire. 
Vol. 9, No. 2, 2020, E-ISSN: 2226-6348@ 2020 HRMARS

Table 4

Scale of Agreement for Needs Analysis Questionnaire

\begin{tabular}{cc}
\hline Likert Scale & Scale of Agreement \\
\hline 1 & Strongly Disagree \\
2 & Disagree \\
3 & Neutral \\
4 & Agree \\
5 & Strongly Agree \\
\hline
\end{tabular}

Two important terms must be understand in FDM are Triangular Fuzzy Number and Defuzzification process. Triangular Fuzzy Number is represented by value m1, m2, and m3. Regarding to this, $\mathrm{m} 1$ represents the minimum value, $\mathrm{m} 2$ represents the reasonable value, whereas $m 3$ represents the maximum value. On the other hand, Triangular Fuzzy Number is used to produce Fuzzy scale for the purpose to translate linguistic variables into the fuzzy number. Figure 1 shows the agreement level of fuzzy scales.

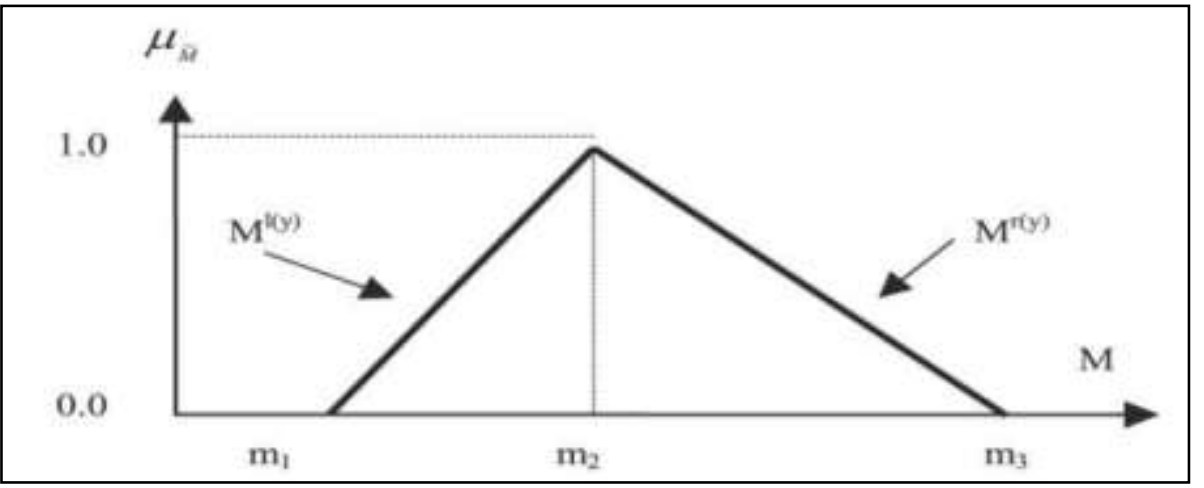

Figure 1 Agreement Level of Fuzzy Scales. Adapted from Hassan, Ibrahim, \& Yaakub, 2018

FDM is a method to maintain or drop an item. The item will be maintained if it meets two conditions, namely; (1) the value of $d$ threshold of the item is equal to or less than $0.2(d \leq 0.2)$; and (2) the percentage of agreement among experts is equal to or exceeds 75 percent $(\geq 75 \%)$ (Lateh, Yaacob, \& Rejab, 2017).

There are many ways of data interpretation for the score of NGT. The acceptance range of score that will be applied in this study is $70 \%$ and above. In other words, if an item achieved the score of above $70 \%$, the item will be accepted. In contrast, if an item obtained the score below $70 \%$, the item may be rejected. At the end, the items will be evaluated based on group score, total score, percentage, and evaluation status. Ranking of constructs and items will be done by comparing these percentages.

\section{Discussion and Conclusion}

As a summary, dyscalculic pupils need to be detected because every pupils should be given the chance to learn according to their needs and abilities (Yahya, Ahmad, \& May, 2019). If they are 
not being detected, they will face problems as they continue learning in the same classroom with the mainstream pupils (May \& Ahmad, 2018).

In this study, the researchers will design and develop Dyscalculia Checklist Instrument (DCI) for dyscalculic pupils in primary schools. The research design for this study is Design and Development Research (DDR) approach. Three phases in DDR are; (1) phase one: needs analysis; (2) phase two: design and development; and (3) phase three: evaluation. Needs analysis questionnaires will be used to identify the needs to develop $\mathrm{DCl}$ for dyscalculic pupils in primary schools. $T$-test and ANOVA will be used to compare the needs among teachers and parents; and to compare the needs among SK, SJKC, and SJKT.

During phase two, FDM will be administered to design and develop the constructs and items in $\mathrm{DCl}$. Eleven experts will be invited to participate in this phase. Then, NGT will be implemented to evaluate the suitability of $\mathrm{DCl}$. Eleven experts will sit in a round table to vote and rate for the constructs and items in DCl. Fuzzy numbers, threshold value, and expert consensus value will be used to be analysed the data in phase two and phase three.

Last but not least, this research is able to contribute to the field of knowledge and bring benefits to many people. This study is very important as it will gives significant benefits to Ministry of Education Malaysia, educators and teachers, dyscalculic pupils, parents of dyscalculic pupils, researchers, and individuals such as educational specialist, therapist, psychologist, occupational therapist, nurses and many other occupations.

\section{Acknowledgement}

Our special thanks go to Sultan Idris Education University (UPSI). The first author would also like to express special thanks to Ministry of Education Malaysia for sponsoring the scholarship of doctoral study. Finally, we would like to express our appreciation to all the dedicated committee members of ICEELST2020.

\section{Corresponding Author}

Noor Aini Ahmad

Department of Special Education, Faculty of Human Development

Universiti Pendidikan Sultan Idris, Malaysia.

Email: noor.aini@fpm.upsi.edu.my

\section{References}

Ahmad, N. A. (2018). Learning Literacy using Augmented Reality (LiTAR): An Application of Learning through Expository, Social and Technical-scientific using Augmented Reality as Learning Strategy. International Journal of Academic Research in Business and Social Sciences, 8(11), 1772-1778.

Alias, N., Siraj, S., Rahman, M. N. A., \& DeWitt, D. (2013). Design and Developmental Research: Emergent Trends in Educational Research. In Siraj, S., Alias, N., DeWitt, D. \& Hussin, Z. (Eds.). Design and Developmental Research: Emergent Trends in Educational Research (pp. 2-15), Malaysia: Pearson.

Bird, R. (2017). The Dyscalculia Toolkit: Supporting Learning Difficulties in Maths (3rd ed.). London: SAGE Publications Ltd. 
INTERNATIONAL JOURNAL OF ACADEMIC RESEARCH IN PROGRESSIVE EDUCATION AND

DEVELOPMENT

Vol. 9, No. 2, 2020, E-ISSN: 2226-6348 @ 2020 HRMARS

Chin, K. E., Pang, V., Wong, K. K., Tan, C. K., \& Lee, K. W. (2014). A Preliminary Study for Dyscalculia in Sabah, Malaysia. The Eurasia Proceedings of Educational \& Social Sciences (EPESS), 1, 217-225.

Jamil, M. R. M., Siraj, S., Hussin, Z., Noh, N. R. M., \& Sapar, A. A. (2019). Pengenalan Asas Kaedah Fuzzy Delphi dalam Penyelidikan Reka Bentuk Pembangunan. Selangor: Minda Intelek Agency.

May, Y. S., \& Ahmad, N. A. (2018). Efficacy of DoCtor WoRM's Module for Year Four Low Achievers. International Journal of Academic Research in Business and Social Sciences, 8(10), 1576-1585.

May, Y. S., \& Ahmad, N. A. (2018). Needs Analysis of DoCtor WoRM's Module in Improving Multiplication Skills among Year Four Low Achievers. International Journal of Academic Research in Business and Social Sciences, 8(5), 931-944.

McKillip, J. (1987). Needs Analysis: Tools for the Human Services and Education. London: SAGE Publications.

Ministry of Education Malaysia. (2013). Malaysia Education Blueprint 2013-2025 (Preschool to Post-secondary Education). Putrajaya: Kementerian Pendidikan Malaysia.

Lateh, N., Yaacob, S. E., \& Rejab, S. N. M. (2017). Applying the Fuzzy Delphi Method (FDM) to Analyze the Expert Consensus Values for Instrument of Shariah-compliant Gold Investment. Pertanika Journal of Social Sciences and Humanities, 25(S), 165-178.

Lay, Y. F., \& Khoo, C. H. (2016). Introduction to Quantitative Approach in Educational Research. Sabah: Penerbit Universiti Malaysia Sabah.

Odu, G. O. (2017). Relationship between Nominal Group Techniques and Concurrent Engineering: A Review. International Journal of Latest Research in Engineering and Technology, 3(3), 47-62.

Perry, F. L., \& Nichols, J. D. (2015). Understanding Research in Education: Becoming a Discerning Consumer. New York: Routledge.

Sahrir, M. S., Alias, N. A., Ismail, Z., \& Osman, N. (2012). Employing Design and Development Research (DDR) Approaches in Design and Development of Online Arabic Vocabulary Learning Games Prototype. Turkish Online Journal of Educational Technology, 11(2), 108119.

Yahya, A.Y., Ahmad, N. A., \& May, Y. S. (2019). A New Dimensional in Teaching Non-verbal Students with Learning Disabilities. International Journal of Academic Research in Business and Social Sciences, 8(12), 2099-2108.

Yunus, H., \& Ahmad, N. A. (2019). A Conceptual Framework for META ProBaca Module in Improving Reading Comprehension and Reading Fluency among Dyslexia Pupils. International Journal of Academic Research in Business and Social Sciences, 9(11), 11871200. 